\title{
Ocorrência de oídio em Zinnia elegans no Estado do Ceará
}

\section{Beatriz Meireles Barguil, Francisco Marto Pinto Viana, Heliel Átila de Oliveira Saraiva}

Embrapa Agroindústria Tropical, Rua Dra. Sara Mesquita, 2270 CEP 60511-110,

Fortaleza- CE $<$ fmpviana@embrapa.cnpat.br $>$

Data da chegada: 01/08/2006. Aceito para publicação em: 10/3/2007.

A espécie Zinnia elegans Jacq., originária do México, é uma planta herbácea pertencente à família Asteraceae. Suas flores pequenas e reunidas em capítulos apresentam diversas cores e formatos, favorecendo sua utilização em bordaduras de parques e jardins de regiões tropicais e subtropicais (Lorenzi, H.; Souza, H.M. Plantas ornamentais no Brasil: arbustivas, herbáceas e trepadeiras. Nova Odessa, SP: Instituto Plantarum. 2001.) de diversos países. Em visita a uma chácara na região metropolitana de Fortaleza - CE foi verificada a presença de crescimento fúngico na face superior de folhas de Z. elegans (Figura 1A), como um pó branco. Amostras de folhas foram encaminhadas ao laboratório de fitopatologia da Embrapa Agroindústria Tropical para exame. A análise macroscópica das amostras mostrou um fungo de micélio superficial, branco, pulverulento, cujos sinais cobria toda a face superior da folha (Figura 1B). As folhas afetadas apresentavam as pontas curvadas, a coloração de verde passando a amarelado, e marrons as mais anteriormente afetadas. $\mathrm{O}$ ataque se limitava às folhas, não afetando às sépalas coloridas. Uma análise mais acurada, realizada ao microscópio óptico, revelou que o fungo associado tinha micélio hialino, conidióforos retos, cilíndricos, com 2 a 4 células; os conídios, também hialinos, 1 célula, formados em cadeias curtas, de formato elipsóides a ovais (Figura 1C), e medindo 25-32,5 x 12,5-18,7 $\mu \mathrm{m}$, dados estes semelhantes ao relatado em literatura especializada para Oidium asteris-punicei Peck. (Weber, G.F. Bacterial and fungal diseases of plants in the tropics. Gainville: University of Florida Press, 1973.). O patógeno é favorecido por lugares sombreados, úmidos e de temperatura amena, podendo infectar a planta em qualquer fase de seu desenvolvimento (Gonçalves, R.D. Oídio da Zinnia. O Biológico,

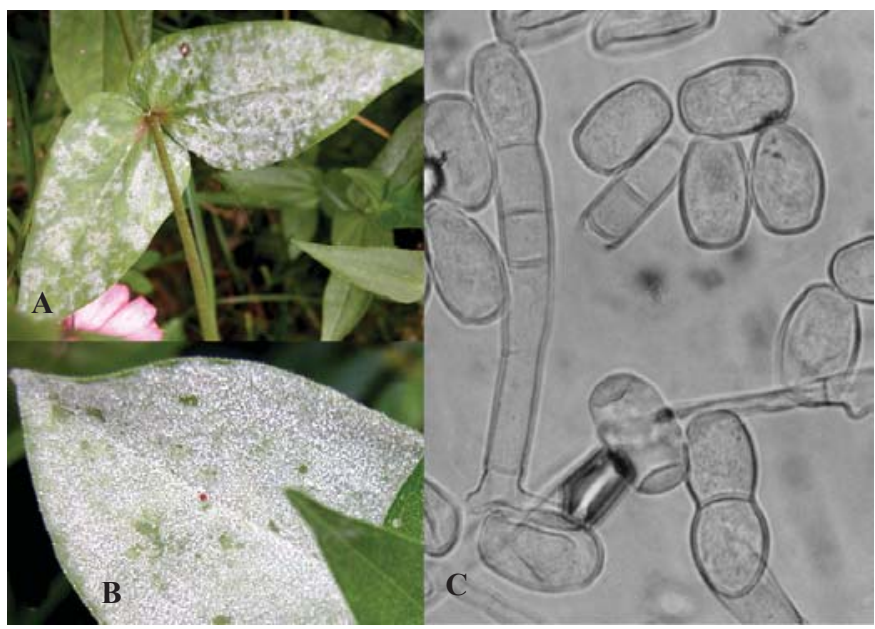

Figura 1. Folhas de zinnia com sintoma típico de oídio (A); detalhe dos sinais do fungo na superfície superior da folha (B); conidióforo e conídios de Oidium asteris-punicei (C) obtidos de Zinnia elegans.

v. 11, p.172-173, 1945.; Pitta, G.P.B.; Cardoso, E.J.B.N.; Cardoso, R.M.G. Doenças das plantas ornamentais. São Paulo, SP: Instituto Brasileiro do Livro Científico, 1990.). Este patógeno também foi observado em outras espécies da família Asteraceae (Wolcan, S.M.; Alvarez, R.E.; Cabrera, M.G. Oídios de ornamentales. p. 419-446. In: Stadnik, M.J.; Rivera, M.C. Oídios. Jaguariúna, SP: Embrapa Meio ambiente. 2001.). Este é o primeiro relato de ocorrência de Oidium asteris-punicei em Zinnia elegans no Ceará. 